Elżbieta Zakrzewska-Manterys

Uniwersytet Warszawski

http://dx.doi.org/10.18778/8088-074-0.03

\title{
Niepełnosprawny jako self-adwokat działający w imieniu i na rzecz innych niepełnosprawnych
}

\section{STRESZCZENIE}

Test dotyczy problematyki self-adwokatury jako działalności służącej wzmocnieniu samostanowienia i emancypacji osób niepełnosprawnych. Jednak warunkiem działań w tym zakresie jest możliwość samodzielnego podejmowania decyzji i refleksyjnego myślenia, do którego osoby upośledzone umysłowo, z racji specyfiki swojej niepełnosprawności, nie są w mniejszym lub większym stopniu zdolne. Tezą tekstu jest więc stwierdzenie, że self-adwokatura powinna być zarezerwowana dla osób niepełnosprawnych, ale w pełni sprawnych intelektualnie. Działania upośledzonych umysłowo self-adwokatów w odniesieniu do osób z własnych środowisk są działalnością pozorną i prowadzą do wytwarzania wiedzy fasadowej na temat ich sprawczości w życiu społecznym.

Słowa kluczowe: self-adwokatura, niepełnosprawność, upośledzenie umysłowe, samostanowienie, emancypacja.

\section{REPREZENTACJA I PRZEDSTAWICIELSTWO}

Jeśli wierzyć deklaracjom Ervinga Goffmana, istnieją okoliczności sprawiające, że aktorzy społeczni doznają całego szeregu upokorzeń z racji noszonego - w sposób jawny 
lub ukryty - piętna. Niepełnosprawność, niezależnie od tego, jakie są jej przyczyny, jest często powodem wykluczenia, a co za tym idzie, także społecznego napiętnowania. W celu poprawienia zasad społecznego funkcjonowania oraz podnoszenia jakości życia osób niepełnosprawnych podejmowanych jest wiele działań zmierzających do włączenia ich do głównego nurtu życia społecznego.

Goffman twierdzi, że w imieniu osób napiętnowanych działać mogą „zorientowani” lub „swoi”. Pierwsza z tych kategorii składa się z osób, które same, co prawda, nie są nosicielami piętna, lecz doskonale znają jego specyfikę. Orientują się, na jakie trudności napotykają w życiu napiętnowani, oraz mają pomysły na to, jak te trudności rozwiązać czy ominąć. Natomiast drugą kategorię tworzą osoby noszące piętno. Według Goffmana to, czy interesy napiętnowanych reprezentują przedstawiciele wywodzący się z nich samych czy też rzecznicy wywodzący się z "normalsów”, zależy w dużej mierze od charakteru piętna. „Jedni mogą być reprezentowani przez nosiciela tego samego piętna, który naprawdę rozumie istotę problemu (jak w wypadku osób głuchych, niewidomych, alkoholików, Żydów), a inni przez kogoś spoza grupy, jak w wypadku byłych skazańców i osób upośledzonych umysłowo” (Goffman 2003: 57)

„Zorientowanym” może być ktoś, kto przeszedł swego rodzaju inicjację i może przyłączyć się do grupy jako pełnoprawny jej członek. Goffman podaje przykład białego chłopca, który wspólnie z czarnoskórymi rówieśnikami brał udział w częstych wyprawach na ryby. Proces wchodzenia w grupę składał się z kilku etapów. Początkowo słowo „czarnuch” w ogóle nie padało podczas interakcji narratora z grupą. W następnym etapie pojawiało się ono, ale z dużą dozą ostrożności. Kolejny etap to używanie przez czarnoskórych kolegów słowa „czarnuch” w żartach. Wreszcie o pełnym członkostwie narratora w grupie świadczyła możliwość używania tego słowa przez niego samego (ibidem: 63). Przykład ten ukazuje, że bycie „swoim” wśród napiętnowanych 
i możliwość bycia ich rzecznikiem to długi i skomplikowany proces, nie zawsze uwieńczony sukcesem. Wymaga on ponadto podzielania przez wszystkich aktorów podstawowej siatki społecznych wartości.

Goffman twierdzi, że jedną z grup, które zwykle są reprezentowane przez kogoś spoza grupy, są upośledzeni umysłowo. Sądzę jednak, że w tym wypadku sytuacja jest specyficzna, bowiem osobami, które najczęściej pełnią funkcję reprezentacji upośledzonych, nie są ci „zorientowani”, którzy świadomie podjęli decyzję o byciu rzecznikiem napiętnowanych, ale są nimi rodzice. Nie było więc wyborem rodziców podjęcie się roli reprezentowania własnych dzieci, zostali w tej sytuacji postawieni przymusowo. Nie wywodzą się z kategorii „normalsów”, lecz sami są nosicielami piętna. Dzieje się tak dlatego, że z jednej strony piętno upośledzenia jest tak dojmujące, że ma zniewalającą moc rozlewania się na najbliższe otoczenie, $\mathrm{z}$ drugiej strony - społeczna niesamodzielność zarówno dzieci, jak i dorosłych osób upośledzonych umysłowo sprawia, że w mniejszym lub większym stopniu muszą być one pod kuratelą innych osób dorosłych dzielących z nimi życie. W tym więc przypadku rodzice nie muszą przechodzić procesu inicjacji, bowiem niejako automatycznie stają się rzecznikami własnych dzieci, o ile ich gdzieś zaraz po urodzeniu nie oddadzą lub z drugiej strony, o ile uporczywie nie twierdzą, że ich dziecko jest „normalne" - co, zwłaszcza w przypadku rodziców małych dzieci, nie należy dziś do rzadkości. W przeważającej jednak mierze środowiska rodziców tworzą kręgi wtajemniczonych, dla których swoboda interakcyjna oznacza robienie sobie żartów z piętna. Mówienie „mój Down” czy „moje mongolątko" może być dla zewnętrznego obserwatora szokujące, a dla nieżyczliwego „normalsa” może być okazją do tworzenia epitetów. Opór i niechęć rodziców małych dzieci do używania wyrażeń tego typu jest świadectwem tego, że nie została jeszcze wypracowana swoboda interakcyjna. Używanie w zamian wyrażeń „neutralnych” (sic!) w rodzaju „moje 
dziecko z zespołem" lub innych jeszcze bardziej omownych oznacza, że piętno jest tak dokuczliwe i doskwierające, że rodzice walczą nie tyle o prawa obywatelskie swych napiętnowanych dzieci, ile o alternatywne sensy, niedostępne dla ogółu społeczeństwa, pozwalające ich dziecko wyjąć z objęć piętna. Tak więc pojęcie „bycie rzecznikiem” jest w tym kontekście wieloznaczne, a pojęcie self-adwokatury oznaczające możliwość samodzielnego decydowania o sobie wymyka się $\mathrm{z}$ zasad racjonalnego zarządzania piętnem.

Wspomnieć jednak należy, że współcześnie coraz bardziej rozpoznawana i uznawana jest rola rodziców w reprezentowaniu swoich dzieci. Jeszcze nie tak dawno rola rodziców była niemal całkowicie pomijana, dominował bowiem „dyskurs terapeutyczny" w odniesieniu do niepełnosprawności, zwłaszcza intelektualnej, a oznaczało to, że dyskutantami byli terapeuci i wyposażający ich w odpowiednią pojęciowość naukowcy. Rodzice, wraz z dziećmi, nie stanowili uczestników dyskursu, ale jego przedmiot. Przykładem „akademickiego" charakteru dysput tego typu jest toczący się obecnie spór, czy należy mówić „osoby niepełnosprawne” czy „osoby z niepełnosprawnością”. Dyskusja ta traktowana jest przez niektórych przedstawicieli świata nauki z niezwykłą powagą, a ważkość problemu może być traktowana jako listek figowy ukrywający brak realnej, życiowej wiedzy na temat specyfiki wspólnego codziennego przebywania $\mathrm{z}$ nosicielami piętna. $\mathrm{W}$ tym też znaczeniu rosnąca rola narracji rodzicielskich może być traktowana jako krok $\mathrm{w}$ kierunku upodmiotowienia relacji społecznych z osobami upośledzonymi umysłowo, self-adwokatura może w tym kontekście być pojęciem oznaczającym działanie na rzecz faktycznych, życiowych potrzeb osób upośledzonych, potrzeb rozpoznanych przez ludzi, którzy ich kochają, a nie przez bezosobowych funkcjonariuszy świata nauki i terapii.

W większości jednak przypadków wysokie kompetencje komunikacyjne i społeczne osób niepełnosprawnych, lecz w pełni sprawnych intelektualnie, nie stoją na przeszkodzie 
ich aktywnemu uczestnictwu w życiu społecznym. Reprezentantami różnych grup osób niepełnosprawnych są więc one same, szczególnie $\mathrm{w}$ obecnych czasach, kiedy procesy emancypacyjne są bardzo zaawansowane. „Gdy osoba z określonym piętnem osiągnie wysoką pozycję zawodową, polityczną czy finansową - od rodzaju grupy zależy, jak wysoka jest to pozycja - to najprawdopodobniej zostanie jej narzucony nowy rodzaj kariery, mianowicie reprezentowanie swojej kategorii” (ibidem: 60). Tak właśnie rozumiem działanie self-adwokatury, czyli procedury, dzięki której osoby niepełnosprawne są reprezentowane $\mathrm{w}$ różnych gremiach i na różnych forach, przez swobodnie wybranych przez siebie i spośród siebie przedstawicieli. Do takich właśnie procedur odnoszą się zapisy prawne dotyczące tej problematyki.

Uchwalona w 2006 r. przez Organizację Narodów Zjednoczonych Konwencja o prawach osób niepełnosprawnych, ratyfikowana przez Polskę w 2012 r., bezpośrednio odnosi się do problemu reprezentowania osób niepełnosprawnych przez upoważnionych do tego członków własnego środowiska. W artykule 29 zatytułowanym „Udział w życiu politycznym i publicznym”, czytamy: „osoby niepełnosprawne będą mogły efektywnie i w pełni uczestniczyć w życiu politycznym i publicznym, na zasadzie równości z innymi osobami, bezpośrednio lub za pośrednictwem swobodnie wybranych przedstawicieli [...]” i dalej: „osoby niepełnosprawne będą mogły efektywnie i w pełni uczestniczyć w kierowaniu sprawami publicznymi, bez dyskryminacji i na zasadzie równości z innymi osobami, oraz [Państwa Strony zobowiązują się do] zachęcania ich do udziału w sprawach publicznych, $\mathrm{w}$ tym do:

(i) udziału w organizacjach pozarządowych i stowarzyszeniach uczestniczących w życiu publicznym i politycznym kraju, a także w działalności partii politycznych i zarządzania nimi,

(ii) tworzenia organizacji osób niepełnosprawnych w celu reprezentowania osób niepełnosprawnych na 
szczeblu międzynarodowym, krajowym, regionalnym i lokalnym oraz przystępowania do takich organizacji" (www.rpo.gov.pl).

Konwencja o prawach osób niepełnosprawnych jest pierwszym międzynarodowym dokumentem w kompleksowy sposób rozpatrującym sytuację osób niepełnosprawnych. Zapisy zawarte w Konwencji są wyrazem dążenia nowoczesnych społeczeństw do zrównania szans życiowych i uczestnictwa społecznego osób niepełnosprawnych, na zasadzie równości z innymi osobami. Należy więc uznać, że zapisy dotyczące strategii związanych z zapewnieniem reprezentacji osób niepełnosprawnych zarówno na forach krajowych, jak i międzynarodowych stanowią wyraz usankcjonowania ruchu self-adwokatury jako jednego $z$ ważnych sposobów zapewniających tym osobom wyjście z trwającej przez dziesięciolecia społecznej izolacji.

Drastyczne przykłady ograniczania podstawowych praw obywatelskich osób niepełnosprawnych podają Colin Barnes i Geod Mercer (2008). Według autorów u progu XXI w. w Wielkiej Brytanii, Australii, USA i w innych krajach naszego kręgu cywilizacyjnego istniały bariery ograniczające możliwość uczestnictwa tych osób w procesach politycznych. W krajach demokratycznych udział osób niepełnosprawnych w partiach politycznych jest bardzo skromny, „co więcej, niepełnosprawni, którzy zostają wybrani, rzadko utożsamiają się z problematyką niepełnosprawności. Odbija to powszechny brak zainteresowania polityki niepełnosprawnością" (Barnes, Mercer 2008: 134). W tej sytuacji coraz większą rolę odgrywają organizacje związane z niepełnosprawnością, wywodzące się głównie z sektora organizacji pozarządowych, które tworzą grupy nacisku starające się wpływać na różne poziomy władzy. Autorzy wyróżniają trzy kategorie takich organizacji: organizacje charytatywne/opiekuńcze, organizacje „jednej sprawy” i organizacje samopomocowe/aktywistów (ibidem: 135). Dwie ostatnie kategorie mogą być prowadzone i zarządzane przez 
samych niepełnosprawnych. Do lat osiemdziesiątych XX w. w Wielkiej Brytanii dominowały organizacje „zdominowane przez pełnosprawnych urzędników, dając niewielką możliwość działania ludziom niepełnosprawnym" (ibidem: 136). Jednak od lat dziewięćdziesiątych powstał ruch oddolnego tworzenia „praktycznych projektów opartych na filozofii samopomocy, których celem było zwiększenie kontroli niepełnosprawnych nad ich życiem" (ibidem: 137). Coraz większego znaczenia nabierają ruchy społeczne tworzone i animowane przez niepełnosprawnych, których celem jest nie tylko walka o prawa obywatelskie, przeciwdziałanie ubóstwu czy braku dostępu do informacji, ale przede wszystkim domaganie się uznania polityki różnorodności. Zgodnie z tą polityką różnorodność jest wzbogacająca zarówno dla mainstreamowej większości, jak i dla różnego rodzaju mniejszości, do których zaliczyć można także niepełnosprawnych.

\section{DZIAŁALNOŚĆ SPOŁECZNA I REALIZACJA WŁASNEJ DROGI}

Istnieją dwie strategie działania osób niepełnosprawnych na rzecz innych niepełnosprawnych. Pierwsza z tych strategii to świadomy wybór drogi społecznika, natomiast druga polega na twórczym realizowaniu siebie i dawanie w ten sposób przykładu własnej autonomii.

Społecznikostwo osób niepełnosprawnych wyraża się w chęci działania na rzecz innych ludzi. Ewa Gorczycka i Tatiana Kanasz, przedstawiając wyniki przeprowadzonych przez siebie badań, piszą: „Wśród największych sukcesów życiowych młodzież niepełnosprawna wskazała te, które są związane z nauką [...] - 49\%. Na drugim miejscu znalazła się samodzielność (15\%), a potem - możliwość pomocy innym ludziom (6\%)" (Gorczycka, Kanasz 2014: 74). Chęć pomocy, wymieniana na trzeciej pozycji wśród deklarowanych 
sukcesów życiowych, może wskazywać na to, że niepełnosprawność jest okolicznością zwiększającą wrażliwość społeczną i przyczynia się do zwracania uwagi na trudności doświadczane przez innych ludzi. Jest to o tyle znaczące, że, jak piszą autorki, „ponad połowie badanych pełnosprawnych studentów brakuje wiedzy, co do zachowań w obecności osoby niepełnosprawnej i ewentualnego udzielenia pomocy. Częściowo wyjaśnia to fakt, że prawie połowa sprawnych studentów nie ma żadnego kontaktu z osobami niepełnosprawnymi spoza uczelni” (ibidem: 115) Autorki prowadziły badania wśród studentów Akademii Pedagogiki Specjalnej, a więc na uczelni, która - jak się wydaje - przyjmuje w swe mury osoby szczególnie predestynowane do zajmowania się, a przynajmniej do rozumiejącego wglądu w specyfikę niepełnosprawności. Mimo to jednak świadomość społeczna studentów tej uczelni na temat problematyki niepełnosprawności jest bardzo skromna. Obrazuje to, z jakimi barierami, o charakterze głównie mentalnym, muszą się zmierzyć osoby niepełnosprawne wybierające drogę pomocy innym ludziom. Zwłaszcza jeśli tymi „innymi ludźmi” są niepełnosprawni koledzy często jeszcze w naszym kraju doświadczający jawnej lub ukrytej dyskryminacji.

Drugą strategią działania na rzecz środowisk osób niepełnosprawnych jest osobiste dążenie do pełnienia ról społecznych cieszących się szacunkiem społecznym i dawanie w ten sposób przykładu wpływającego na zmianę wizerunku osób niepełnosprawnych wśród ogółu społeczeństwa.

Jedna $\mathrm{z}$ niesłyszących studentek mówi w wywiadzie: „Postanowiłam wziąć kierunek prawo na KUL, a później, po czterech latach, postanowiłam wziąć drugi kierunek pedagogikę. Robiłam też różne kursy, różne szkolenia, jeśli chodzi o komputery, naukę języka migowego, a później takie pod moje zainteresowania i hobby to kurs instruktora łyżwiarstwa figurowego ukończyłam i mam zamiar uczyć dzieci. A jeszcze na przykład inne zainteresowania to także modeling i różne konkursy piękności dla osób niesłyszą- 
cych, na których byłam dwa razy, rok temu w Gruzji, a dwa lata temu w Stanach Zjednoczonych" (Zakrzewska-Manterys 2015: 40).

Kolejny przykład to postać niepełnosprawnego poety, Tadeusza Geniusza. „Tadeusz czując się dłużnikiem ludzi, którzy w niego zainwestowali, by mógł swobodnie tworzyć, chciał, żeby taką samą szansę mieli inni twórcy ograniczeni chorobą. Udało mu się wzbudzić zainteresowanie i powstało Ogólnopolskie Stowarzyszenie Twórczości Artystycznej Osób Niepełnosprawnych 'Symbioza' ” (Siemież 2004: 222).

Przykłady te wskazują na to, że podstawą działania osób niepełnosprawnych na rzecz innych niepełnosprawnych musi być zanurzenie w świecie sensów i wartości. Godność człowieka manifestuje się nie w tym, że sama jest przedmiotem troski, ale w tym, że objawia się w niezależnym i twórczym działaniu. Jeśli - podążając tropem jednego z najwybitniejszych współczesnych filozofów, Hansa-Georga Gadamera - udział w życiu społecznym nazwiemy „udziałem w grze”, to właściwości człowieka świadczące o jego człowieczeństwie można zaliczyć do reguł, na których zasadza się gra. „Gra - pisze Gadamer - ma swoiste istotowe odniesienie do tego, co poważne. [...] Udział w grze tylko wtedy przecież wypełnia swój cel, gdy grający całkowicie oddaje się grze. Fakt, że gra jest w pełni grą, nie wynika z zewnętrznego odniesienia gry do powagi, lecz tylko z powagi podczas gry. Kto nie traktuje gry poważnie, ten ją psuje. Sposób istnienia gry nie pozwala graczowi odnosić się do niej jak do przedmiotu. Grający wie dobrze, czym jest gra, i że to, co on czyni, 'jest tylko grą, ale nie wie, co sam tutaj 'wie'” (Gadamer 1993: 121-122). Można więc powiedzieć, że istotą uczestnictwa w społecznym świecie sensów jest poważne traktowanie wszystkich okoliczności tworzących strukturę gry, a jest to możliwe tylko wtedy, gdy „zapominamy" o regułach gry, to znaczy nie nastawiamy naszej uwagi na reguły, pozwalając im po prostu „działać”. Przymioty człowieka: godność, samostanowienie, wolność nie są 
treścią gry, ale warunkiem jej podjęcia, nie mogą więc, aby nie utracić powagi, być przedmiotem szczególnego namysłu. Innymi słowy, ich powaga polega na tym, że nie przedstawiają same siebie, ale manifestują się przy okazji brania „na serio” udziału w życiu społecznym.

\section{SELF-ADWOKATURA UPOŚLEDZONYCH UMYSŁOWO}

W Słowniku pedagogiki specjalnej pod hasłem self-adwokatura (self-advocacy) czytamy: „bezpośrednie występowanie we własnym imieniu przez osoby $\mathrm{z}$ niepełnosprawnością intelektualną, które stają się rzecznikami własnych spraw. Dzięki idei self-adwokatury osoby z upośledzeniem umysłowym uczą się mówić o swoich potrzebach, prawach i oczekiwaniach, podejmować autonomiczne decyzje oraz sprawować większą kontrolę nad własnym życiem i osobiście reprezentować swoje interesy na zewnątrz, a także zabiegać o respektowanie swoich praw. Przyczynia się to do ich aktywizacji, zwiększenia samodzielności oraz rozszerzenia zakresów bezpośredniego uczestnictwa w życiu społecznym. Wpływa także na zmianę sposobu myślenia o sobie, traktowania siebie jako osoby z możliwościami i prawami. Ponadto buduje poczucie podmiotowości osób z niepełnosprawnością intelektualną, ich godności, autonomii i odpowiedzialności" (Kupisiewicz 2013: 323).

Powyższy cytat jest dosyć długi, ale zawarte jest w nim wszystko, co można powiedzieć o self-adwokaturze osób upośledzonych umysłowo. Nieliczne źródła podejmujące to zagadnienie powtarzają niemal dokładnie to, co zawarte jest $w$ wydawnictwie encyklopedycznym. Nie zetknęłam się z publikacją, która rozszerzałaby rozumienie pojęć w wydaniu słownikowym lakonicznych, enigmatycznych i niezwiązanych z praktyką codziennego życia. Stanowią one nieznośną mieszankę patosu i infantylizmu. 
Małgorzata Kupisiewicz, autorka hasła „self-adwokatura", powołuje się na organizację parasolową zrzeszającą ruchy self-adwokatów z różnych krajów Europy - European Platform of Self-Advocates (www.inclusion-europe.eu). Jednak strona internetowa tej organizacji jest praktycznie martwa, ostatni wpis został dokonany w 2012 r., a roczne sprawozdania z działalności zawierają 2-3 strony „tekstu łatwego do czytania" o treści równie fasadowej jak cytowane hasło słownikowe. Design jest zaprojektowany jak dla przedszkolaków, choć ruch self-adwokatów dotyczy przecież ludzi dorosłych. Wbrew szumnym zapowiedziom walki o wolność i godność, wyłania się stąd wizerunek osób niepełnosprawnych intelektualnie jako ludzi strasznie żałosnych i zmanipulowanych, w dodatku nieprzemawiających własnym głosem.

Głównym, o ile nie jedynym, źródłem wiedzy o self-adwokaturze w Polsce, jest Zarząd Główny Polskiego Stowarzyszenia na Rzecz Osób z Upośledzeniem Umysłowym (PSOUU) oraz wybrane, co aktywniejsze, koła terenowe tego Stowarzyszenia. Na stronie internetowej PSOUU (organizacja we wrześniu 2015 r. zmieniła nazwę na Polskie Stowarzyszenie na Rzecz Osób z Niepełnosprawnością Intelektualną) istnieje zakładka „self adwokaci”, a także „platforma self-adwokatów” i „self adwokaci piszą”. Treści zawarte w tych zakładkach są jednak bardzo ubogie (www.psouu. org.pl).

Niemniej jednak wokół problematyki self-adwokatury dzieją się ważne wydarzenia. W 2014 r. PSOUU opublikowało poradnik zatytułowany Scenariusze zajęć dla self adwokatów. Jest to, jak można przeczytać na stronie internetowej Stowarzyszenia "Poradnik metodyczny dla profesjonalistów o tym, jak wspierać osoby z niepełnosprawnością intelektualną i przygotowywać je do bycia self-adwokatem". We wrześniu 2015 r. odbyła się ogólnopolska konferencja zorganizowana przez Koło Terenowe PSOUU w Jarosławiu „Usłysz nasze głosy: obywatel na pierwszym 
miejscu”. Wszędzie tam odnaleźć można pustosłowie, zupełny brak konkretnych odniesień do codziennego życia i patetyczne szafowanie górnolotnymi frazesami. W podręczniku odnaleźć też można zalecenia podobne do szamańskich zaklęć: jeśli zrobisz to, co zaleca podręcznik, twoje życie nagle się odmieni, a jeśli tego nie zrobisz, pozostaniesz w swym dotychczasowym pożałowania godnym stanie.

Z powyższych rozważań wynika, że pojęcie self-adwokatury zostało wyjęte $\mathrm{z}$ kontekstu oznaczającego walkę o prawa podmiotowe osób o wysokich kompetencjach komunikacyjnych i społecznych, lecz naznaczonych piętnem niepełnosprawności - osób, których dotyczą zapisy prawne mówiące o równouprawnieniu, jak na przykład zapisy zawarte w Konwencji o prawach osób niepełnosprawnych, o której była mowa na początku niniejszego tekstu. W to miejsce pojawia się kontekst, z którego wynika, że prowadzona za pomocą self-adwokatury walka osób niepełnosprawnych intelektualnie $\mathrm{z}$ dyskryminacją ma polegać na pretendowaniu do bycia kimś innym niż one faktycznie są. Co to bowiem znaczy, że „dzięki idei self-adwokatury osoby z upośledzeniem umysłowym uczą się [podkr. EZM] mówić o swoich potrzebach, prawach i oczekiwaniach...”. Jeśli osoby upośledzone umysłowo nie umiały mówić o swoich prawach dopóki nie zetknęły się z ideą self-adwokatury, to z pewnością nie zdobędą takiej wiedzy po zetknięciu się z tą ideą. Idea self-adwokatury nie jest czarodziejską różdżką i nie może zastąpić procesu, który trwa znacznie dłużej niż godziny spędzone na szkoleniach. Proces ten nazywa się socjalizacją. Trwa on przez całe życie i nie jest podatny na chałupnicze przy nim manipulowanie, nawet jeśli manipulator ma najlepsze intencje. Wynika z tego, że traktuję self-adwokaturę w odniesieniu do osób upośledzonych umysłowo jako zaprzeczenie idei podmiotowego traktowania tych osób oznaczającą uszanowanie ich specyfiki. 


\section{POLITYKA PODMIOTOWEGO TRAKTOWANIA}

Trudności w rozważaniu tej problematyki wynikają z tego, że pojęcie „niepełnosprawność” jest nad wyraz niejednoznaczne. Z jednej bowiem strony, we wszystkich oficjalnych dokumentach, gdy mowa o niepełnosprawności, wymienia się różne jej przyczyny, w tym także obniżoną sprawność intelektualną (https://pl.wikipedia.org). Jednak z drugiej strony, w licznych opracowaniach naukowych, w których mowa o podmiotowości i samostanowieniu osób niepełnosprawnych, dokonuje się zawężenia omawianej grupy. Przykładowo, Hanna Żuraw, prowadząc badania na temat udziału osób niepełnosprawnych w życiu społecznym, deklaruje: „Odwoływanie się do refleksyjności, do krytycznej myśli jednostki umiejącej dokonywać świadomych i trafnych ocen wydarzeń cyklu życia wymagało zawężenia badanej grupy do ludzi, których dysfunkcje nie naruszają zdolności sądzenia i rozważania” (Żuraw 2008: 112). Deklaracja ta staje się czymś niebudzącym wątpliwości, gdy bada się niepełnosprawnych studentów (np. Czechowska-Bieluga 2010; Rozmus 2010).

Pozycja osób niepełnosprawnych intelektualnie wśród ogółu niepełnosprawnych jest szczególna. Wielu autorów, wypowiadając się o konieczności pełnego uczestnictwa w życiu społecznym, kulturalnym, artystycznym czy politycznym osób niepełnosprawnych, pomija milczeniem tę kategorię, bowiem jej specyfika wymaga odrębnego omówienia. Pominięcie to jest tym łatwiejsze, że osoby niepełnosprawne intelektualnie stanowią w Polsce grupę bardzo nieliczną, choć w większości krajów Unii Europejskiej jest ich znacznie więcej. W roku 2004 osoby upośledzone umysłowo stanowiły w Polsce 2,5\% wszystkich niepełnosprawnych, w roku 2009 wskaźnik ten wynosił 4\% (Bartkowski 2014: 50-51), podczas gdy w krajach Unii Europejskiej wskaźnik ten od kilku lat waha się od 5\% do 15\% (Żuraw 2010: 23). Z powodu tak małej liczebności łatwo „zapomnieć” o istnieniu tej kategorii osób i tak też, moim zdaniem, często się dzieje. 
Autorzy, którzy włączają osoby niepełnosprawne intelektualnie do swoich analiz, czynią zwykle zastrzeżenia, że nie należy tych osób mechanicznie traktować jako subkategorii ogólnej nazwy „niepełnosprawność”. Katarzyna Ćwirynkało zwraca uwagę, że dopiero od początków XXI w. zaczęto zwracać uwagę na sytuację osób dorosłych z niepełnosprawnością intelektualną, a więc braki i zapóźnienia w tej dziedzinie są rezultatem wielowiekowych zaniedbań. Coraz bardziej dziś dominujące tendencje normalizacyjne i emancypacyjne idą w parze „ze wzrastającą przeciętną długością życia osób z niepełnosprawnością, także intelektualną, oraz z oddolnymi inicjatywami różnych grup społecznych (np. self-adwokatów i innych osób związanych z ludźmi z określoną niepełnosprawnością)" (Ćwirynkało 2013: 202). Sytuację dorosłych osób z niepełnosprawnością intelektualną autorka uważa za szczególnie trudną, ponieważ bardzo bogate wsparcie instytucjonalne zwykle kończy się wraz z zakończeniem edukacji. W tym kontekście ruch self-adwokatury traktowany jest jako jedna $\mathrm{z}$ nielicznych możliwości przybliżania osób niepełnosprawnych do głównego nurtu życia społecznego. Jednakże oddolne inicjatywy podejmowane przez osoby z różnymi innymi rodzajami niepełnosprawności są traktowane jako bardziej funkcjonalne. Bowiem po pierwsze, w stosunku do osób niepełnosprawnych intelektualnie self-adwokaci uczestniczą przy wsparciu innych osób działających w ich imieniu, głównie rodziców i opiekunów, po drugie, niezbędny jest szczegółowy instruktaż specjalistów. Wydany przez PSOUU poradnik Scenariusze zajęć dla self-adwokatów opatrzony jest komentarzem: „poradnik metodyczny dla profesjonalistów, o tym jak wspierać osoby z niepełnosprawnością intelektualną i przygotowywać je do bycia self-adwokatem”. Wsparcie profesjonalistów jest niezbędne, bowiem „osoby niepełnosprawne intelektualnie w stopniu znacznym i głębokim ze względu na rozległość swoich dysfunkcji w oczywisty sposób nie mogą stać się osobami niezależnymi od pomocy 
innych, bowiem potrzebują wsparcia w najprostszych czynnościach" (Kijak 2013: 239).

Dorosłość osób z niepełnosprawnością intelektualną jest pełna sprzeczności i nieprzezwyciężalnych trudności:

- Większość z tych osób przebywa w Warsztatach Terapii Zajęciowej, których statutowym obowiązkiem jest prowadzenie rehabilitacji zawodowej. Mimo to WTZ opuszcza rocznie ok. 1,59\% uczestników, spośród których zaledwie $21,7 \%$ trafia na otwarty rynek pracy (www. raport_koncowy_WTZ).

- Wskaźniki aktywizacji zawodowej tej grupy osób oscylują wokół zera, a jeśli zatrudnienie nastąpi, najczęściej jest krótkotrwałe, finansowane projektowo i kończy się wraz z zakończeniem realizacji projektu.

- Osoby niepełnosprawne $\mathrm{z}$ orzeczeniem o niezdolności do pracy nie mogą zarejestrować się jako osoby bezrobotne, a w związku z tym „nie mogą korzystać z proponowanych w tym zakresie usług i narzędzi oferowanych przez urzędy pracy. Mogą jedynie otrzymać status osoby poszukującej pracy, ale zakres usług wobec nich ogranicza się do instrumentów doradztwa” (Fajfer-Kruczek 2013: 118). Jest to jeden $\mathrm{z}$ najpoważniejszych paradoksów systemowych dotyczących zatrudnienia osób niepełnosprawnych.

- Niezależność materialna czy możliwość samodzielnego zamieszkania również stoją pod znakiem zapytania: „System pomocy społecznej często wyklucza samodzielne utrzymanie. Dostępny system mieszkalnictwa chronionego jest słabo rozwinięty, co w znacznym stopniu ogranicza możliwości usamodzielnienia się tych ludzi” (Kijak 2013: 245).

W tej sytuacji ruch self-adwokatów można traktować bardziej jako wyraz myślenia życzeniowego niż jako rzeczywisty, ugruntowany w warunkach ekonomicznych i legislacyjnych, ruch społeczny. Podjęcie działań systemowych w kierunku zmiany niekorzystnego położenia osób 
z niepełnosprawnością intelektualną jest czymś znacznie trudniejszym niż głoszenie górnolotnych haseł. Takie systemowe działania podejmowane są w bardzo wąskim zakresie, a jeśli już są podejmowane, to z pewnością nie przez self-adwokatów ani stojących za nimi profesjonalistów.

\section{KONKLUZJE}

Możliwość występowania przez osoby niepełnosprawne w imieniu i na rzecz własnych społeczności to wyraz tendencji emancypacyjnych i jedno z najbardziej spektakularnych, pozytywnych obliczy społeczeństwa obywatelskiego. Niezależnie od przyczyn niepełnosprawności, każda osoba ma prawo do uczestnictwa w życiu publicznym i politycznym, zgodnie z własnymi preferencjami. Nie oznacza to jednak, że wszyscy w jednakowym stopniu mogą korzystać ze wszystkich przywilejów społeczeństwa obywatelskiego. Ten fałszywy egalitaryzm nie ma nic wspólnego z równouprawnieniem. Jest raczej wyrazem zakamuflowanej dyskryminacji, bowiem opiera się na polityce równościowej, zgodnie z którą „wszyscy jesteśmy tacy sami”. Polityka ta nie daje osobom „odmiennym” prawa do głośnego wyrażania własnej odmienności, lecz nakazuje im pretendować do bycia kimś „takim samym” jak większość. Ruch self-adwokatury w odniesieniu do osób niepełnosprawnych intelektualnie można w tym kontekście rozumieć jako nakłanianie ich do takiego zachowania, „jak gdyby” były osobami zdolnymi do pogłębionej autorefleksji, nie traktując tym samym poważnie ich prawa do bycia człowiekiem upośledzonym umysłowo, a więc takim, który już ma udział w pełni człowieczeństwa - nie musi się o to starać, chodząc na szkolenia z zakresu self-adwokatury. 


\section{BIBLIOGRAFIA}

Badanie sytuacji warsztatów terapii zajęciowej. Raport końcowy, Warszawa, wrzesień 2014, PFRON: www.raport_koncowy_ WTZ (1).pdf

Barnes Colin, Geod Mercer (2008), Niepetnosprawność, Wydawnictwo Sic!, Warszawa.

Bartkowski Jerzy (2014), Położenie społeczno-ekonomiczne i jakość życia osób niepelnosprawnych w Polsce, [w:] Barbara Gąciarz, Seweryn Rudnicki (red.), Polscy niepetnosprawni. Od kompleksowej diagnozy do nowego modelu polityki społecznej, Wydawnictwa AGH, Kraków, s. 45-103.

Czechowska-Bieluga Marta (2010), Kompetencje społeczne studentów niepełnosprawnych jako determinanta ich kariery zawodowej, [w:] Stanisława Byra, Monika Parchomiuk (red.), Student niepetnosprawny. Wybrane konteksty, Wydawnictwo UMCS, Lublin, s. 71-79.

Ćwirynkało Katarzyna (2013), Dlaczego koniec edukacji nie jest poczatkiem integracji społecznej? Osoby dorosłe $z$ niepełnosprawnościa intelektualna w lokalnej przestrzeni, [w:] Zenon Gajdzica (red.), Człowiek z niepetnosprawnościa w rezerwacie przestrzeni publicznej, Oficyna Wydawnicza „Impuls”, Kraków, s. 201-220.

Fajfer-Kruczek Ilona (2013), O niemożliwej integracji społecznej osób niepełnosprawnych bez integracji systemowej sektorów polityki państwa. Analiza paradoksów prawnych i działań wdrożeniowych, [w:] Zenon Gajdzica (red.), Człowiek z niepetnosprawnościa $w$ rezerwacie przestrzeni publicznej, Oficyna Wydawnicza „Impuls”, Kraków, s. 110-123.

Gadamer Hans G., (1993), Prawda i metoda. Zarys hermeneutyki filozoficznej, Inter Esse, Kraków.

Goffman Erving (2003), Piętno. Rozważania o zranionej tożsamości, Gdańskie Wydawnictwo Psychologiczne, Gdańsk.

Gorczycka Ewa, Tatiana Kanasz (2014), Niepetnosprawni studenci Akademii Pedagogiki Specjalnej w opiniach własnych i środowiska akademickiego, Wydawnictwo Akademii Pedagogiki Specjalnej, Warszawa.

Kijak Remigiusz J. (2013), Kontrolująca funkcja systemu pomocy społecznej jako przeszkoda w osiaganiu niezależności $\dot{z} y$ ciowej przez dorosłe osoby z głębsza niepełnosprawnościa 
intelektualna, [w:] Zenon Gajdzica (red.), Człowiek z niepetnosprawnościa $w$ rezerwacie przestrzeni publicznej, Oficyna Wydawnicza „Impuls”, Kraków, s. 221-247.

Kupisiewicz Małgorzata (2013), Słownik pedagogiki specjalnej, Wydawnictwo Naukowe PWN, Warszawa.

Rozmus Paweł (2010), Niepetnosprawność nie przeszkadza żyć. Analiza sieci kontaktów towarzyskich, spędzania wolnego czasu $i$ korzystania $z$ mediów przez niepetnosprawnych studentów, [w:] Barbara Gąciarz (red.), Niepetnosprawni studenci w społeczności akademickiej. Źródła sukcesów i porażek $w$ integracji społecznej i aktywizacji zawodowej, Wydawnictwo IFiS PAN, s. 95-117.

Siemież Małgorzata B. (2004), Rola twórczości literackiej w życiu niepełnosprawnego człowieka - na przykładzie Tadeusza Geniusza, [w:] Jarosław Bąbka (red.), Człowiek niepełnosprawny w różnych fazach życia, Wydawnictwo Akademickie "Żak”, Warszawa, s. 214-225.

Zakrzewska-Manterys Elżbieta (2015), Sytuacja edukacyjna niepełnosprawnych studentów, [w:] Ewa Giermanowska, Agnieszka Kumaniecka-Wiśniewska, Mariola Racław, Elżbieta Zakrzewska-Manterys, Niedokończona emancypacja. Wejście niepełnosprawnych absolwentów szkół wyższych na rynek pracy, Wydawnictwa Uniwersytetu Warszawskiego, Warszawa.

Żuraw Hanna (2008), Udział osób niepetnosprawnych w życiu społecznym, Wydawnictwo Akademickie „Żak”, Warszawa.

\section{Strony internetowe}

https://pl.wikipedia.org

www.inclusion-europe.eu

www.psouu.org.pl

www.rpo.gov.pl/pl/konwencja-o-prawach-osob-niepelnosprawnych 


\section{DISABLED AS A SELF-ADVOCATE ACTING FOR AND ON BEHALF OF OTHER DISABLED}

\section{(Summary)}

The paper deals with the problem of self-advocacy treated as an activity serving in behalf of disabled persons' empowerment and emancipation. But the base of this activity is ability to independent decision making and reflective thinking, to which people with mental handicap are, more or less, incapable. The thesis of the paper is then the statement that self-advocacy should be applied to disabled, but fully intellectually capable, persons. The actions undertaken by mentally handicapped self-advocates towards persons from their social environment are apparent and lead to development of facade knowledge about their abilities in social life.

Keywords: self-advocacy, disability, mental handicap, empowerment, emancipation. 